\title{
PORT STATE CONTROL: A COMMENT ON THE TOKYO MOU AND ISSUES OF INTERNATIONAL LAW*
}

\author{
Ted L. McDorman ${ }^{* *}$
}

\section{INTRODUCTION}

In December 1993 regional port state control came to the Pacific with the acceptance of the Memorandum of Understanding on Port State Control in the Asia-Pacific Region, ${ }^{1}$ known as the Tokyo Port State Control MOU. The Tokyo Port State Control MOU came into effect in April 1994.

Port state control encourages the appropriate local maritime authorities to inspect vessels voluntarily in port to ensure that those vessels have been constructed, and are equipped, crewed and operated in compliance with the standards set by the relevant international treaties. Where vessels are detected as not being in compliance with the standard-setting conventions, the port state may prevent the offending vessel from leaving until the defects have been remedied. The goal is that as countries and regions adopt port state control, enforcement of international vessel standards will be enhanced and vesselowners will undertake to comply with the standards voluntarily rather than risk detection of sub-standard vessels and face potential delays and penalties. The primary aim of port state control, therefore, is the identification and elimination of sub-standard vessels.

Port state control has not increased the number of international treaties which govern vessel-source marine pollution, rather port state control is a cooperative mechanism designed to enhance compliance with existing conventions. ${ }^{2}$ A recent comprehensive study by Dr. EDGAR GoLD listed 83 interna-

\footnotetext{
- This contribution is a revised version of a paper presented at the SEAPOL-Kitakyushu International Conference on Port and Distribution Center Development held in Kitakyushu, Japan, 28-29 August 1998.

"* Faculty of Law, University of Victoria, Victoria, British Columbia; Oceans Institute of Canada, Halifax.

${ }^{1}$ Memorandum of Understanding on Port State Control in the Asia-Pacific Region, 1 December 1993, reprinted in ROY S. LEE and MORITAKA HAYASHI (eds.), New directions in the law of the sea: regional and national developments (Dobbs Ferry, N.Y.: Oceana Publications, Release 97-1, November 1997). There have been several amendments made to the Tokyo MOU since its original adoption. The most recent, complete version of the Tokyo MOU and the one referred to in this contribution can be found by visiting the website www.iijnet.or.jp/tokyomou/.

${ }^{2}$ See text infra accompanying notes 31-32 regarding the international legal status of the regional Port State Control arrangements.
}

Asian Yearbook of International Law, Volume 7 (Ko Swan Sik et al., eds.

(C) Kluwer Law International; printed in the Netherlands), pp. 229-241 
tional treaties and related instruments as dealing with vessel-source marine environmental pollution. ${ }^{3}$ The treaties can be grouped into four categories. First are treaties which create jurisdictional competences for national governments to deal with national-flag vessels and, more importantly, foreign-flag vessels that are within waters claimed by a state. The most important of these treaties is the 1982 United Nations Convention on the Law of the Sea. ${ }^{4}$ Second are the conventions which create standards for vessel construction and operation and are directed specifically to the issue of marine environmental pollution. The most important of these treaties is the International Convention for the Prevention of Pollution from Ships, 1973 (MARPOL), ${ }^{5}$ its 1978 Protocol $^{6}$ and the subsequent amendments. Third are the treaties that create liability and compensation schemes in the event of vessel-source marine pollution damage. The two best known of these treaties are the International Convention on the Civil Liability for Oil Pollution Damage, 1969 (CLC) ${ }^{7}$ and the International Convention on the Establishment of an International Fund for Compensation for Oil Pollution Damage, 1971 (the Fund Convention), ${ }^{8}$ both of which have been updated by amendments and protocols. Finally, there are the general maritime safety conventions that apply to all ocean-going vessels. An important example is the International Convention for the Safety of Life at Sea, 1974 (SOLAS). ${ }^{9}$ Port state control is a new approach to preventing marine environmental pollution by encouraging compliance with the second and fourth categories of international treaties - the standard setting conventions.

This contribution will focus on the development and operation of port state control and has four sections: a section on the international law of the sea that forms the basis of port state control; a brief section on the history of regional port state control agreements; a section which examines the key operational aspects of the Tokyo Port State Control MOU; and a short conclusion.

\footnotetext{
${ }^{3}$ See: Edgar Gold, Gard Handbook on Marine Pollution (Gard: Arendal, Norway, 2nd edition, 1998) 56 and 88-95.

${ }^{4}$ United Nations Convention on the Law of the Sea, reprinted in 21 ILM (1982) 1261 (hereinafter: CLOS 1982).

${ }^{5}$ International Convention for the Prevention of Pollution by Ships (MARPOL), reprinted in 12 ILM (1973) 1319.

${ }^{6}$ Protocol Relating to the Convention for the Prevention of Pollution from Ships (MARPOL), reprinted in 17 ILM (1978) 546.

${ }^{7}$ International Convention on Civil Liability for Oil Pollution Damage, reprinted in 9 ILM (1970) 45.

${ }^{8}$ Convention on the Establishment of an International Fund for Compensation for Oil Pollution Damage, reprinted in 11 ILM (1972) 284.

${ }^{9}$ International Convention for the Safety of Life at Sea, 1184 UNTS 2.
} 


\section{INTERNATIONAL LEGAL ISSUES REGARDING PORT STATE CONTROL}

\subsection{Port State v. Flag State}

International law embraces the fiction that ships are floating land masses of the state where the vessel is registered and that the law applicable to the ship is the law of the state of registry - the flag state. ${ }^{10}$ Thus, regarding international vessel standard treaties, a vessel is required to comply with those treaties binding upon the flag state. Moreover, enforcement of applicable treaties against vessels is to be undertaken by the flag state.

What port state control has accomplished is the addition of another group of states, those states with ports visited by vessels, with the responsibility to enforce international conventions which create vessel standards. Flag state jurisdiction has not been altered. Rather, what has occurred is an assertion of the international legal principle, that, within a port, the host state has absolute jurisdiction over visiting vessels in the same manner as if the visiting vessel were a foreign citizen vacationing or doing business in the host country. The result being that a visiting vessel is subject to and must comply with the laws and regulations of the host country.

There is no conflict in international law between the authority of a port state over a visiting vessel and the authority of the flag state respecting that vessel. International law is clear that the authority of the port state is superior to that of the flag state while the vessel is in port. As two writers state: "By entering foreign ports and other internal waters, ships put themselves within the territorial sovereignty of the coastal state". ${ }^{11}$ While port state superior authority is the rule, there are several potential exceptions. First, if the visiting vessel is a government vessel, issues of sovereign or diplomatic immunity may arise. Second, if a vessel is not voluntarily in port but had to put into port because of an emergency or weather, there may be a limitation in customary international law on the authority of the port state regarding that vessel. ${ }^{12}$

While there is no conflict in international law between the authority of a port state and the flag state, the legal certainty does not accurately reflect the tension between the port state and the flag state. Traditionally, port states rarely interfered with foreign flag vessels voluntarily in port. Unless the activity of a visiting vessel or on board a visiting vessel directly affected the populace of the port, host states declined to exercise legal authority over visiting vessels. ${ }^{13}$ International commerce and sensibilities regarding national sovereignty supported

\footnotetext{
${ }^{10}$ CLOS 1982 Art.91(1). See generally: E.D.BROWN, The international law of the sea (Aldershot: Dartmouth Publishing, 1994) at 287.

" R.R.CHURCHILl and A.V.LOWE, The law of the sea (Manchester: Manchester University Press, 2d.ed., 1988) at 54.

${ }^{12}$ Ibid. at 54 and 56-57.

${ }^{13}$ Ibid. at 54-55.
} 
port state forbearance in exercising authority over visiting foreign vessels. Port state control, while clearly supportable by international law, does interfere with the traditional expectations of visiting foreign vessels to be left alone while in port.

\subsection{Access to port}

An important corollary to the international legal principle that a host state has authority over foreign vessels voluntarily in port is that a port state can prohibit the entry into port of any vessel. Put another way, customary international law does not recognize the existence of a right of access to a port by a foreign vessel. Such a right of access may exist under international treaty law, for example, the 1923 Convention and Statute on the International Regime of Maritime Ports. ${ }^{14}$ International trade agreements, such as those administered by the World Trade Organization, ${ }^{15}$ also might be construed in such a way that a failure to allow port access could amount to a breach of an international trade law obligation. ${ }^{16}$ It is clear from the above that, subject to treaty obligations, a host state can deny access to its ports and impose what conditions it thinks reasonable on foreign vessels seeking access to a port. The economic realities of ocean trade, however, operate to keep conditions on access to port from becoming so restrictive that vessels elect to bypass the ports of certain countries.

\subsection{Application of laws by the port state}

The superior position of the authority of a port state over visiting vessels vis-à-vis the authority of the flag state can lead to the situation where a port state can apply an international treaty against a visiting vessel even though the flag state of the visiting vessel is not a party to that treaty. Usually an international treaty is only applicable and enforceable between states which are parties to the treaty. Flag states have argued that port states should not impose international agreements against visiting vessels to which the flag state is not a party. The flag state argument is based on the concern that a commercial vessel may face conflicting laws, that of the port state and the flag state. Moreover, it is argued that since a vessel is always subject to flag state laws and, only while in port subject to host state laws, that the law of the flag state should be respected. However, under principles of international law, once a foreign vessel voluntar-

\footnotetext{
${ }^{14}$ Convention and Statute on the International Regime of Maritime Ports, 58 LNTS 285.

${ }^{15}$ See Agreement Establishing the World Trade Organization, reprinted in 33 ILM (1994) 1144, in particular Annex 1 for a listing of the agreements administered by the W.T.O. The most important agreement is the General Agreement on Tariffs and Trade, 55 UNTS 194.

${ }^{16}$ See LOUISE DE LA FAYETTE, "Access to ports in international law", 11 International Journal of Marine and Coastal Law (1996)1 at 18-21, who argues that international trade law does not interfere with a port state's right to deny a foreign flag vessel access to port.
} 
ily enters into a port of a country, that vessel becomes subject to the laws and regulations of the host country irrespective of whether those laws and regulations are based upon treaties to which the flag state of the visiting vessel is also a party.

It must be noted that the laws and regulations that a port state can apply to a visiting vessel are not without legal limit. Customary international law directs that a port state can only enforce laws that relate to activities of a foreign vessel that take place while the vessel is in port. This includes construction, design, safety, crewing and equipment standards that a vessel must meet. The 1982 Law of the Sea Convention, which can be taken to be customary international law on this point, provides that a port state also can enforce laws that relate to activities of a foreign vessel that took place in the waters of the host state prior to a vessel's entry into port. The qualification is that the laws to be enforced by a port state must have been enacted 'in accordance with' the Law of the Sea Convention or applicable international rules and standards for vessel-source pollution prevention, reduction and control. ${ }^{17}$ Where an activity (for example, a pollution discharge) of a foreign vessel takes place on the high seas or in the waters of a third state, and that activity does not affect the port state, customary international law does not permit a host state to enforce its laws regarding that activity against a visiting foreign vessel in its ports. ${ }^{18}$ In such situations, the law that is applicable is that of the flag state or the coastal state where the activity took place. ${ }^{19}$ Article 218 of the Law of the Sea Convention, referred to as the port state enforcement provision, attempts to create an enforcement capacity for a port state in the situation where a foreign vessel discharges a pollutant on the high seas or in the waters of another state in contravention of existing international standards. ${ }^{20}$ It is highly questionable whether Article 218 of the Law of the Sea Convention has emerged as part of customary international law. Moreover, few countries have extended their law to embrace a port state enforcement power of this type and none of the regional port state control accords discussed below have adopted the contents of Article 218 of the Law of the Sea Convention.

${ }^{17}$ CLOS 1982 Art.220(1).

${ }^{18}$ The most obvious exception to this statement concerns vessels engaged in piracy activities. Other excepted activities may include slave trading, drug trafficking and unauthorized broadcasting on the high seas. See Part VII of the CLOS 1982.

${ }^{19}$ This limitation that exists on a port state is the result of the concept of extra-territoriality. See, generally, T.L.MCDORMAN, "Port state enforcement: a comment on Article 218 of the Law of the Sea Convention", 28 Journal of Maritime Law and Commerce (1997) 305 at 312314. For the exceptional activities noted in supra note 18, the basis of the jurisdiction of a port state would be the universality principle of jurisdiction as accepted in customary international law or the specifics of the 1982 Law of the Sea Convention.

${ }^{20}$ For a full discussion of Art.218 port state enforcement, see MCDORMAN, loc.cit.n.19 at 305322. 


\subsection{Departure from port}

A final international law issue to be noted concerns the authority of a host state to detain, seize or arrest, and thus prevent the departure from port of a visiting foreign vessel.

The right of a foreign vessel to depart port is tied to the penalties that may be imposed against the vessel because of breaches of the statutory law of the host state or because of court orders and arrest that may arise from commercial disputes. International law does not inhibit local courts from imposing injunctions or like measures arising from commercial disputes against foreign vessels. Moreover, the ability of a host state to detain a foreign vessel in port as a result of a commercial dispute would appear to be consistent with international law, although qualifications on this power of detention may arise from the $1952 \mathrm{Ar}$ rest of Sea-Going Ships Convention. ${ }^{21}$

The more significant issue here is the ability of a foreign vessel to depart port where the host state has determined that the vessel is not in compliance with laws and standards related to the construction, design, equipment, operation or crewing of a vessel. There does not appear to be any restriction in international law regarding the type of penalty that can be levied against a foreign vessel which, while in port, breaches such laws or standards. Thus, detention, arrest or seizure of a visiting vessel would be possible. The 1982 Law of the Sea Convention only imposes limitations on penalties where foreign vessel activities, e.g. pollution discharges which breach the host state's laws, take place in the host state's territorial sea or exclusive economic zone. In such situations, only monetary penalties are to be imposed, except if, in the territorial sea, the alleged illicit activity was "a wilful and serious act of pollution". ${ }^{22}$ More generally, the Law of the Sea Convention in Articles 219 and 226(1)(c) permits a host state to take 'administrative measures' to prevent any vessel deemed 'unseaworthy' and which "would present an unreasonable threat of damage to the marine environment" from departing port. ${ }^{23}$ The flag state of a vessel detained pursuant to these provisions would be entitled to pursue prompt release of the vessel through the dispute settlement procedures of the Law of the Sea Convention. $^{24}$

\footnotetext{
${ }^{21}$ International Convention for the Unification of Certain Rules Relating to the Arrest of Seagoing Ships, 439 UNTS 193. See GEORGE C. KASOULIDES, Port state control and jurisdiction (Dordrecht: Martinus Nijhoff, 1993) at 26.

${ }^{22}$ CLOS 1982 Art.230(1) and (2).

${ }^{23}$ See ShabTaI RosenNe and AleXANDER YANKov, United Nations Convention on the Law of the Sea, 1982: A Commentary, Vol.4 (Dordrecht: Martinus Nijhoff, 1991) at 273-278.

${ }^{24}$ See the various learned articles in 11 International Journal of Marine and Coastal Law(1996) No. 2 and the commentary on the first prompt release case before the Law of the Sea Tribunal by BERNARD H. OXMAN, “The M/V 'Saiga'“, 92 AJIL (1998) 278-282.
} 


\subsection{Summary}

International law of the sea provides that a port state has extensive authority over vessels voluntarily in port. Subject to treaty rights, access to a port can be denied and conditions on foreign vessel access can be imposed. There are few limitations on the laws that a host state can apply to a visiting vessel regarding construction, design, equipment, operation and crewing. Finally, the host state has wide powers of detention, arrest and seizure of vessels in port where local laws are breached.

\section{HISTORY OF REGIONAL PORT STATE CONTROL MOUS}

While international law has long accepted that a host state has authority over foreign vessels voluntarily in port, port states have been reluctant to upset the traditional approach of the flag state being responsible for enforcing marine pollution prevention and vessel safety laws against their vessels. This reluctance of a host state to impose strict laws against visiting vessels arose from economic realities. Competition between ports of different countries operated to ensure that a country did not adopt port laws unfavourable to trade. Moreover, strict environmental laws or other port laws regarding visiting vessels could increase the cost of goods. Finally, the shipping industry has long argued that host states applying differing local standards would create a checker-board of regulations that would increase compliance costs unreasonably and inhibit ocean trade. While certain states, such as the United States, because of their unique geographical, economic and political situation, could unilaterally apply strict port laws, other countries feared adoption of strict port laws would have the significant economic repercussions suggested by the shipping industry. However, the increasing concern about sub-standard vessels plying the oceans of the world - by the public, as a result of publicity surrounding oil tanker disasters such as the Exxon Valdez; by the shipping industry, because of their poor public image; and by governments, in response to the public and industry - created a demand for a co-operative or regional approach to encourage port states to enhance enforcement of marine pollution and vessel safety laws against visiting vessels.

The first such regional arrangement of port states was created in Europe through the 1982 Memorandum of Understanding on Port State Control in Implementing Agreements on Maritime Safety and Protection of the Marine Environment, ${ }^{25}$ known as the Paris Port State Control MOU. This was followed a decade later by the 1992 Latin American Agreement on Port State Control, ${ }^{26}$

\footnotetext{
${ }^{25}$ Memorandum of Understanding on Port State Control in Implementing Agreements on Maritime Safety and Protection of the Marine Environment, reprinted in 21 ILM (1982) 1.

${ }^{26}$ The Latin America Port State Control agreement is discussed briefly in GoLD, op.cit.n.3 at 76.
} 
then came the previously noted 1993 Tokyo Port State Control MOU, the 1996 Caribbean Port State Control MOU, ${ }^{27}$ the 1997 MOU on Port State Control in the Mediterranean Region and preparations are being made for a port state control MOU for the Indian Ocean.

All the port state control arrangements are substantively similar and follow the model of the 1982 Paris Port State Control MOU. ${ }^{28}$ For example, all the port state control MOUs contain wording in the preamble which indicates the need for a regional approach "to prevent the operation of substandard ships" in order "to avoid distorting competition between ports". ${ }^{29}$ Moreover, the preambles note that the 'principal responsibility' for implementing international standards on a vessel continues to rest with the flag state..$^{30}$ In other words, all the regional port state control MOUs are aware of the need to strike a balance between exercising the authority international law cedes to a port state with the responsibilities of flag states and, more importantly, economic realities.

Regional port state control has been approached through constitutive documents labelled as MOUs. The participants are the maritime authorities of the various countries rather than the states themselves. The intention was "not to enter into new contractual and binding obligations". ${ }^{31}$ As a result, it can be stated that, as a matter of form, the MOUs are not international treaties. Operationally, however, the MOUs have all the characteristics of a functioning treaty with national maritime authorities applying the wording and fulfilling the expectations of the MOUs. In reality, only in the most technical sense are the regional port state control MOUs not international treaties. ${ }^{32}$

\section{THE TOKYO PORT STATE CONTROL MOU}

The various port state control MOUs set out "guidelines for an improved and harmonized system of port state control and strengthened co-operation in the exchange of information" ${ }^{33}$ The idea of the port state control MOUs is that in each port of a region regular inspections will be undertaken of visiting vessels to determine whether the visiting vessels are in compliance with the standards laid down in specified international treaties. The information on the in-

\footnotetext{
${ }^{27}$ Memorandum of Understanding on Port State Control in the Caribbean Region, reprinted in LEE and HAYASHI, op.cit.n.1, Release 97-1, November 1997.

${ }^{28}$ The Paris Port State Control MOU is analized in detail in KASOULIDES, op.cit.n.21 at 142182.

${ }^{29}$ Tokyo Port State Control MOU, Preamble, paras. 6 and 7.

${ }^{30}$ Tokyo Port State Control MOU, Preamble, para. 5.

${ }^{31}$ KASOULIDES, op.cit.n.21 at 151, see also at 143-144.

${ }^{32}$ The need to adopt differing approaches to international instruments so as to avoid form controlling or undermining substance is explained in detail in DOUGLAS M. JOHNSTON, Consent and commitment in the world community (New York: Transnational Publishers, 1997), in particular at 118-185, 211-246 and, regarding MOUs, at 284-285.

${ }^{33}$ GoLD, op.cit.n.3 at 74 .
} 
spections is to be shared among the port authorities of the region to avoid multiple inspections of vessels which are complying with standards, while allowing suspect vessels to be carefully monitored. All the vessel inspecting authorities are to apply the same international standards and implement equivalent procedures respecting inspection and reporting. Where sub-standard vessels are detected, the port authority is to detain the visiting vessel until the defect is remedied, or where that is not practical, allow the vessel to proceed to a port where the defect can be remedied.

The key points in the above overview of the operation of port state control under the regional MOUs are: what countries are part of a regional port state control agreement and how is the MOU administered; what international conventions are to be enforced by the port authorities; which and how many vessels are to be inspected; and when can a visiting foreign flag vessel be detained. The Tokyo Port State Control MOU will be reviewed looking at these four questions.

\subsection{Adhering states and MOU administration}

There are fifteen states, plus Hong Kong, which adhere to the Tokyo Port State Control MOU. ${ }^{34}$ The Asian states are: the People's Republic of China, Indonesia, Japan, Korea, Malaysia, the Philippines, the Russian Federation, Singapore, and Thailand. The South Pacific states are: Australia, Fiji, New Zealand, Papua New Guinea, and Vanuatu. Canada is also a participating country. The Solomon Islands and Vietnam have signed the Tokyo MOU but have not yet formally accepted it. The United States, which has its own extensive programme of port state control, ${ }^{35}$ has observer status.

The Tokyo MOU, like its regional cousins, creates a Port State Control Committee. The Committee is composed of representatives from all the adhering state authorities, observers from several United Nations organizations and other observers as the Committee deems appropriate. As noted, the United States is an observer. Amongst other things, the Port State Control Committee has the responsibility to develop and review inspection guidelines, approve amendments to the MOU, and develop and review procedures for the exchange of information. A small Secretariat, located in Tokyo, assists the work of the Committee.

\footnotetext{
34 Annual Report on Port State Control in the Asia-Pacific Region 1997, website iijnet.or.jp/tokyomou/.

${ }^{35}$ See David G. Dickman, "Port states, the United Nations Convention on the Law of the Sea, and the U.S. Coast Guard's Port State Control Initiative", paper presented at the 1995 Law of the Sea continuing legal education course held in Seattle at the Washington School of Law.
} 


\subsection{International conventions enforced}

The Tokyo Port State Control MOU sets out eight international conventions which are to be enforced by the port authorities against all visiting vessels: ${ }^{36}$

- the 1966 International Convention on Load Lines; ${ }^{37}$

- the 1974 Safety of Life at Sea Convention (SOLAS); ${ }^{38}$

- the 1978 Protocol to the 1974 SOLAS Convention; ${ }^{39}$

- the 1973 Convention for the Prevention of Pollution from Ships (MARPOL), and the 1978 Protocol; ${ }^{40}$

- the 1978 Convention on Standards for Training, Certification and Watchkeeping for Seafarers; ${ }^{41}$

- the 1972 International Regulations for Preventing Collisions at Sea; ${ }^{42}$

- the 1969 Convention on Tonnage Measurement of Ships; ${ }^{43}$ and

- the 1976 Merchant Shipping (Minimum Standards) Convention of the International Labour Organization (ILO Convention No.147). ${ }^{44}$

The goal is that each inspecting authority will apply a uniform set of standards as contained in the designated international treaties. However, section 2.4 of the Tokyo MOU directs that each inspecting authority is only to apply those international conventions which are in force and binding for that port state. All the above noted treaties are legally in force. The record of state ratification of the treaties in the Tokyo MOU region is very good. Four of the eight instruments have been ratified by all the Tokyo MOU states. ${ }^{45}$ The 1978 Protocol to the 1974 SOLAS Convention has not been ratified by Canada, Fiji, Papua New Guinea, the Philippines or Thailand. MARPOL has not been ratified by Fiji, New Zealand, the Philippines or Thailand. The Philippines is the only Tokyo MOU state not to be a party to the 1972 Collision Regulations. However, it appears that many of the Tokyo MOU states are not parties to the $1976 \mathrm{Mer}-$ chant Shipping (Minimum Standards) Convention. Variation in enforcement

\footnotetext{
${ }^{36}$ Tokyo Port State Control MOU, section 2.1.

${ }^{37}$ International Convention on Load Lines, 640 UNTS 133, entered into force 21 July 1968.

${ }^{38}$ SOLAS Convention, supra n.9, entered into force 25 May 1980.

${ }^{39}$ Protocol of 1978 Relating to the International Convention for the Safety of Life at Sea, reprinted in 17 ILM (1978) 579, entered into force 1 May 1981.

${ }^{40}$ MARPOL Convention, supra n.5, and the 1978 Protocol of the MARPOL Convention, supra n.6. Entered into force 2 October 1983.

${ }^{41}$ International Convention on Standards of Training, Certification and Watchkeeping for Seafarers, United Kingdom Treaty Series 1984:50 (Cmnd.9266). Entered into force 28 April 1984.

${ }^{42}$ Convention on the International Regulations for Preventing Collisions at Sea, reprinted in 12 ILM (1973) 734. Entered into force 15 July 1977.

${ }^{43}$ International Convention on Tonnage Measurement of Ships, United Kingdom Treaty Series 1982:50 (Cmnd.8716). Entered into force 18 July 1982.

${ }^{44}$ Merchant Shipping (Minimum Standards) Convention (ILO Convention No.147), reprinted in 15 ILM (1976) 1288. Entered into force 28 November 1981.

${ }^{45}$ State ratification for the first seven listed treaties is based on information from the International Maritime Organization (IMO) as of 1 September 1998. See the IMO website: www.imo.org/imo/convent/status.htm.
} 
will also exist where amendments are made to any of the eight conventions, since the Tokyo MOU directs that, while amendments are part of the listed conventions, a port state is only to enforce amendments which it has formally adopted. $^{46}$

\subsection{Vessels inspected}

The Tokyo Port State Control MOU, like the other regional port state control MOUs, provides that the standards in the designated international conventions are to be applied against all vessels irrespective of whether the visiting vessel's flag state is a party to the relevant convention. The wording of the Tokyo MOU directs that port authorities are to ensure that "no more favourable treatment" is given vessels from a state not a party to the relevant treaty than a vessel from a state a party to the relevant treaty. ${ }^{47}$

In an ideal world, all vessels visiting a port would be inspected by the relevant host authorities. This, of course, is not practicable. A key component of regional port state control is to ensure that sufficient inspections are undertaken to provide a high degree of confidence that sub-standard vessels are being detected and to provide an impetus to ship owners to voluntarily comply with vessel standards. The Paris Port State Control MOU deals with this issue by encouraging each state to inspect 25 per cent of all vessels which enters its ports. ${ }^{48}$ This 25 per cent requirement has lead to 90 per cent of all vessels using ports in the European region being inspected. ${ }^{49}$ The Tokyo MOU takes a different approach. The Tokyo MOU sets a regional target that, by the year 2000, 50 per cent of all ships operating in the region are to be inspected, leaving the question of how many inspections each state is to undertake to be determined annually by the Port State Control Committee.

The Tokyo MOU provides that in selecting vessels to inspect port authorities are to "pay special attention" to, amongst others: passenger ships; oil tankers, gas carriers and similar ships "which may present a special hazard"; vessels which have had recent deficiencies; and vessels which have not been inspected within the previous six months. ${ }^{50}$

In both 1996 and 1997, the 50 per cent threshold was reached in the AsiaPacific region. In 1997, regional port authorities inspected 12,957 vessels from 102 countries. ${ }^{51}$ The estimated number of vessels in the Tokyo MOU region

\footnotetext{
${ }^{46}$ Tokyo Port State Control MOU, section 2.4, sentences 2 and 3.

${ }^{47}$ Tokyo Port State Control MOU, section 2.5 and see KASOULIDES, op.cit.n.21 at 155-157.

${ }^{48}$ Paris Port State Control MOU, section 1.3.

${ }^{49}$ Gerhard KIEHNE, "Investigation, detention and release of ships under the Paris MOU on Port State Control: A view from practice", 11 International Journal of Marine and Coastal Law (1996) 217 at 219.

${ }^{50}$ Tokyo Port State Control MOU, section 3.3.

${ }^{51}$ Annual Report 1997, supra n. 34.
} 
was 24,779 , thus approximately 52 per cent of vessels using ports in the region were inspected.

\subsection{Deficiencies and detention}

Under the Tokyo MOU detailed procedures have been adopted and are applied regarding the conducting of vessel inspections. Understanding the commercial nature of ocean trade and the cost factors involved in extensive port time, the Tokyo MOU provides that inspection activities are to be conducted so as "to avoid unduly detaining or delaying a ship". 52 Another consideration regarding detention of visiting vessels is the potential of lawsuits by the vessel owner where a port authority inappropriately detains a vessel. ${ }^{53}$

In the case of deficiencies, inspecting authorities are to secure rectification and provide information to other port authorities on the results of inspections. Only where a deficiency is "clearly hazardous to safety, health or the environment" may a port authority require removal of the hazard prior to allowing a vessel to depart. ${ }^{54}$ Thus, vessel detentions are to be rare.

Of the 12,957 vessels inspected pursuant to the Tokyo Port State Control MOU in 1997, 58 per cent $(7,518)$ of the vessels were found to have deficiencies. ${ }^{55}$ However, only 830 vessels from 53 states were actually detained. Thus, only 11 per cent of vessels with deficiencies were detained and only 6.4 per cent of all vessels inspected were detained.

\section{CONCLUSION}

The legal jurisdiction exercised by port authorities over foreign vessels voluntarily in port pursuant to regional port state control MOUs is consistent with the international law of the sea. A port state could exercise even greater authority over visiting vessels than that suggested under the regional port state control MOUs and not be in violation of international law. However, the regional port state control MOUs are an attempt to balance the legal capacity of a port state with the economic needs and traditional expectations of the global shipping industry and to avoid competition among ports.

How effective have regional port state control MOUs been in reducing marine environmental pollution and the number of sub-standard vessels? The results appear to be favourable, although mixed. Regarding reducing marine environmental pollution, Dr. EDGAR GOLD attributes the 99.9995 per cent safe

\footnotetext{
52 Tokyo Port State Control MOU, section 3.11, first sentence.

${ }^{53}$ This issue is commented upon briefly by JOHN HARE, "Port State Control: Strong medicine to cure a sick industry" 26 Georgia Journal of International and Comparative Law (1997) 571 at 590-592.

${ }^{54}$ Tokyo Port State Control MOU, section 3.7.

${ }^{55}$ Annual Report 1997, supra n.34.
} 
arrival of oil to its destination, in part, to enhanced port state controls. ${ }^{56}$ RONALD B. MITCHELL attributes tanker owner compliance with international vessel standards to the increased probability of detection and detention arising in large measure from regional port state control arrangements. ${ }^{57}$ However, Professor JOHN HARE has observed that vessel losses have not decreased, which might be an expected outcome from effective port state control and the reduction of sub-standard shipping. ${ }^{58}$ Based on a detailed study of the workings of the Paris Port State Control MOU, PETER B. PAYOYO noted that the number of sub-standard vessels had not gone down, but had in fact increased. ${ }^{59}$ PAYOYO was optimistic, however, that as aged fleets were replaced and regional port state control MOUs became more wide-spread, that "truly dramatic results" would occur.

Based on the favourable, but mixed, evidence of the effectiveness of regional port state control MOUs to the present, all observers agree that there is an important future for regional port state control initiatives like the Tokyo Port State Control MOU and that ultimately the results will be safer ships and cleaner seas.

${ }^{56}$ GOLD, op.cit.n. 3 at 317-318: "Ship-source marine pollution has been reduced to the lowestever level through a combination of stricter coastal and port state controls, better shipboard technology and operations and overall value of the product."

57 Ronald B. Mitchell, Intentional oil pollution at sea: Environmental policy and treaty compliance (Cambridge: MIT Press, 1994), at 267.

${ }^{58}$ HARE, loc.cit.n.53 at 592-593.

${ }^{59}$ PETER BAUTISTA PAYOYO, "Implementation of international conventions through port state control: An assessment”, 18 Marine Policy (1994) 379 at 392. 